\title{
Hellenic references in Edgar Allan Poe's critique on contemporary society
}

\author{
DIMITRIOS TSOKANOS* \\ Universidad de Almería
}

Received: 25/08/2015. Accepted: 02/05/2016.

\begin{abstract}
Edgar Allan Poe's bicentenary triggered new translations and research on his life and works. Studies have been conducted by several noteworthy scholars such as Silverman (1991) and Peeples (1998 and 2004) indicating that the selected tales in this essay are Poe's political message to the society of his time. The presence of Latin and Hellenic phrases and names in Poe's critique has been indicated in the past. However, despite the existence of numerous analyses with respect to the Latin motifs in Poe's narratives, even in Lois Vines' Poe Abroad (1999) there has been no research dedicated to the apparent presence of Hellenic references in Poe's works. Moreover, a methodic study devoted to the presence of the Hellenic domain in Poe's storytelling has never been undertaken. Presenting promismcging evidence for an extensive study, I aim to delve into these references and identify the reasons why Poe turned to Greece as a source of inspiration.
\end{abstract}

KEYWORDS: Edgar Allan Poe, ancient Greece, Hellenic language, philhellenism, Hellenic history, Hellenic tragedy.

\section{INTRODUCTION}

Edgar Allan Poe (1809-1849) is considered a central figure of the Romantic period in the United States and of American literature in general. His stories have repeatedly attracted the attention of renowned scholars and literary experts. Many aspects of his tales and poems have already been reviewed and in recent decades several in-depth analyses of Poe's life and work have been undertaken by renowned scholars in the United States (Hoffmann, 1972; Kennedy, 2001, 2006; Peeples, 1998, 2004; Silverman, 1991). The interest in the American author also prompted the study of his tales and poems under different perspectives: for instance,

*Address for correspondence: Dimitrios Tsokanos. Universidad de Almería. La Cañada de S. Urbano, 04120, Almería, Spain; e-mail: tsokd12@gmail.com. 
Baum explored Homer's influence on Poe by indicating Poe's probable use of Helen of Troy as a source of inspiration and as a means to portray his idea of his "first, purely ideal love" for Mrs. Stanard (1949: 293) whereas Vincelette (2008) delved into Poe's use of Archimides' "Eureka" as a title of his homonymous work.

In 2009, the bicentennial of Edgar Allan Poe's birth was celebrated with an array of conferences worldwide-Philadelphia and Amherst in the U.S., or Albacete and Cáceres in Spain, or the isle of Crete, to name a few. These major literary events were followed by a wide variety of studies dealing with Edgar Allan Poe's life (Ackroyd, 2008) and works (González Moreno \& Rigal Aragón, 2010; Hayes, 2009; Rigal Aragón, 2011; and, more recently, Cantalupo, 2014). In addition, Poe's oeuvre received a revived interest in Greece with the release of new translations of his fiction and poetry-Schina (2013) published more recent translations of a large part of Poe's tales and poems.

The presence of Edgar Allan Poe outside the United States was thoroughly covered in a volume edited by Vines, Poe Abroad (1999), which delved into the American author's influence in Europe, South America and Asia. Quite surprisingly, there has neither been an indication regarding Poe's presence in Greece nor clues that illustrate Hellenic motifs within his works, apart from the sole exception of Filippakopoulou's study published in Translated Poe (2014), a volume edited by Esplin and Vale de Gato. In her contribution, Filippakopoulou barely scratches the surface of the proposed topic since she only analyzes the manner in which Greek translators chose to present Poe's narratives in Greek. Thus, the present research could be characterized as an opportunity to probe into an almost completely uncharted field, presenting promising evidence of a Hellenic influence on Poe's works and setting the foundations for a later systematic study.

Within Poe's tales, one can establish the author's inclination to create stories that portray the death of a beautiful woman and his desire to explore the metaphysical world. His stories also delve into the relationship between love and hate, the communication between the inner self and the alter ego, and the power of death upon the world of the living. Based on what has been voiced up until very recently, Poe's "Mellonta Tauta", "The Colloquy of Monos and Una" and "The Conversation of Eiros and Charmion" could be perceived as Poe's skepticism or as a portrayal of a criticism on his contemporary society. Carlson (2007) scrutinized the political-philosophical dimension of the last two narratives and he demonstrated Tate's indication of an emerging Platonism in the American author's criticism. He also set forth Poe's notion of a cataclysmic end as a means for society to reach "spiritual Unity" (Carlson, 2007: 6). More recently, McGann explored Poe's vision of politics through his works. According to his conclusions, the American poet was intensely interested in public matters; yet, his concerns are not extensively delineated in his storytelling (2014: 146-200). Nevertheless, again according to McGann, when Poe seems to have wished to castigate society he never mitigated his criticism, as I shall later demonstrate. 
While reading Poe's narratives, one frequently comes upon references that allude to Classical literature, either Latin or Greek. In fact, there are various cases of the author's plain use of Hellenic and Latin words or epigraphs in his storytelling. For instance, readers encounter an epigraph written entirely in Latin in "Eleonora" whereas in "The Conversation of Eiros and Charmion" Poe utilizes the ancient Greek language- " $\Pi v \rho \sigma$ or $\pi \rho o \sigma o l \varsigma \omega$ " [sic] (2014: 386) - ; hence, the impression that Poe was influenced by Classical texts while composing his tales emerges. However, despite the numerous assessments of the political and social critique in Poe's narratives, a systematic examination of the Hellenic references in Poe's attempt to construct his criticism has never been attempted. No indication of philhellenic tendencies is even mentioned in Marchand's (1934) thorough inquiry on Poe's role as a social critic. Although Poe's Classical education has been unearthed by several investigations in the past—such as those of Silverman (1991) or Stashower (2014)—, the focus on its effect on Poe's storytelling has not been extensively reviewed. Norman's (1934) attempt to demonstrate Poe's inclination to Latin sources and the Latin language indicates the inexistence of a corresponding investigation on the Hellenic aspect of the matter. Even Zimmerman's extensive research on the rhetorical devices utilized by Poe does not proceed any further than mentioning that Aristotelian logic is present in "Mellonta Tauta", indicating that this specific element is an important guide for the political aspect of the tale (2005: 641). His research is also an analysis that delineated the rhetoric style of Poe's works; yet, it did not delve into the depths of the proposed topic. Thus, in an effort to fill in a gap in this specific field of Poe studies, I aim to investigate the key features of Poe's selected tales that could connect Poe's critique with the use of references originating from Classical Greece. Also, I will attempt to offer an additional link of "The Conversation of Eiros and Charmion" to Classical literature, as well as to interpret the reasons why Poe chose these specific Hellenic connections in his works. Since there is no evidence regarding the latter part of my research, my analysis is based on existing literature in order to draw conclusions.

The examination of the selected tales has to be conducted in the same manner as other similar investigations which probed the existence of Hellenic motifs in modern and early modern literature — such examples are the approaches by Peris (1980) or Silberschlag (1977). Following a similar methodology, I intend to introduce the tales with their brief summary combined with an extensive analysis of what has been affirmed up until now regarding their interpretations so that a more spherical outline of their contemporary interpretations is provided. All indications of the presence of the Hellenic language will be delved into. In the same vein, all the texts will be compared and aligned with selected extracts originating from Classical literature so that one can evaluate the possible connections between Poe's narratives and Classical Greece.

Upon examining Richard's (2009) comments, I observed that the literary minds of the American antebellum Romantic period came together with democracy in an attempt to emphasize nature and the rejoicing of the present rather than the past. In this sense, according 
to Richard, American Romanticism probably opted to forsake the classics even though they frequently made use of Platonic notions and ideas (2009: 120-151). Notwithstanding, Poe seems to insist on a perpetual utilization of values and Hellenic notions encountered in Hellenic literature. Hence, the following question arises: Why did Poe embrace the Hellenic realm? In answer to this, I will attempt to interpret the reasons why these particular allusions to the Hellenic texts were made by further looking into Poe's literary idols and events that might have rendered Greece one of the American author's sources of inspiration.

\section{POE'S CRITIQUE ON SOCIETY USING THE ANCIENT GREEK LANGUAGE: "MELLONTA TAUTA"}

Edgar Allan Poe's fable "Mellonta Tauta" is a tale written in the form of a letter which is supposedly composed in the very distant future, during the year 2848. It was first published in 1850 and its plot is set on board a hot air balloon or airship of the future named "Skylark" which carries hundreds of people on a voyage. The fictional component of the narrative has been pointed out by a variety of scholars (Brunet, 1997; Levine \& Levine, 1986), along with its satiric tone, which has also been investigated very recently (Gunn, 2010).

According to the narrator, this trip is supposed to be a vacation- "all bound on a pleasure excursion" (Poe, 2014: 350). However, she finds it to be tedious and tiresome. A large part of the story focuses on the description of the world the narrator lives in and its comparison with the world of the ancient times upon which she seems to be quite misinformed. The first part of the tale introduces the reader to the world of the narrator, Pundita, and her image of it. The most important element in her monologue is, according to Hoffman, "her account of the political institutions of that distant and misguided age" (1972: 194).

This tale has previously been characterized as Poe's attempt to convey a political message as well as his criticism of the society of his time (Martínez López, 2011: 172). As Hoffman contends, "whenever Edgar has a Great Message he sends it to the reader in a letter [...] Now he does it again with 'Mellonta Tauta'. Only this time he signs it, 'yours everlastingly, Pundita"” (Hoffman, 1972: 193). Through "Pundita" Edgar Allan Poe criticizes the democracy of his time, and this particular view is also shared by notable scholars (Marshall, 2011; Vincelette, 2008). His criticism had to be set in a delicate, careful form since, as Hoffman affirms, "so subversive a tract could not be issued in the administration of President Fillmore. It had to be predated 2848" (1972: 194). Regardless of the time the story is set in, readers spot Poe's attempt to scrutinize the Great American Experience making it seem superficial. In fact, his tale is a dystopian satire aimed to strike the numbness of his contemporary society, as set forth by Martínez López (2011: 167). 
While focusing on the period in which this tale was composed, one could observe that Poe's wife was severely affected by tuberculosis and he himself was going through a particularly challenging period in financial terms. As Kennedy proposes, Virginia's illness and later demise provoked an "inward chaos" in the American author's idiosyncrasy (2001: 115). This disarray had caused Poe's dissociation from society, which, later on, led to "deep cynical assessments of democracy and progress", as Peeples claims (1998: 155). Hoffman also adds that American democracy had never done anything for Edgar Allan Poe (1972: 196), and all these events might have led to the American author's denunciation of the political scene of his time. The following extract, taken from Marchand's article on Poe's life at that period, vividly demonstrates and confirms Poe's social criticism: "his stand on the larger general questions of social reform, democracy, and progress as it was understood by industrial Whiggery, is hardly open to doubt [...]. Poe had little faith in social reform, with its emphasis on the improvement of society [...]. Poe was hostile, even questioning the sincerity of the reforming spirit" (1934: 33).

A closer look at this satirical story reveals that elements originating from the Hellenic tragedy are concealed in it. To begin with, the title of the tale, "Mellonta Tauta"-a choice of words which is the exact phonetic representation of the corresponding words taken from the ancient Greek language-, seems to have been borrowed from the concluding lines of Sophocles' Antigone. As indicated by Martínez López's analysis of the tale, 'the chorus conclusion at the close of the play suggests that, although the gods punish the proud, punishment brings wisdom. Antigone is a play of State control, about the right of an individual to reject society's limitations on freedom to perform perceived obligations; it is also about Sophocles' defense of natural law and civil disobedience. Finally, Antigone is also about the extent to which hubris brings along the moral and physical destruction of the States" (2011: 172). The word hubris which the above literary critic refers to could actually be determined as pride, insolence and outrage. In this sense, the above indications are closely connected to Poe's political message. According to Papazu, "Poe raises his voice against all attempts to mutilate reality in a Procrustean bed, whether it be by the man's technical endeavor to 'control' the 'natural laws', to get 'dominion' over nature, and over his fellow beings" (1989: 126). In an attempt to uncover the reason why the author might have chosen this particular title, it is interesting to note that Poe uses ancient Greek to envision and anticipate a morbid and dreary future for contemporary civilization. As Papazu stresses, "the deep cultural crisis which Poe senses in a variety of modern phenomena means a refusal of all spiritual values, a refusal of the past and of eternity" (1989: 135). Hence, the literal translation of Poe's "Mellonta Tauta"- "The things that are in the near future"-leads to the belief that Poe may have used the Hellenic language to indicate his objections regarding contemporary society.

Additionally, as Peeples indicated, Poe may have used this particular title in order to indicate that democracy will ultimately lead to "mob rule" (1998: 156). Hence, readers can 
infer that Poe quotes Sophocles in order to give a sharp warning against the totalitarian, oppressive proclivities of modern society. Since public opinion of his time would not accept such rebellious messages, as Hoffman noted (1972: 194), Poe probably used ancient Greek as a means to disguise his nonconformity.

Evidently, Edgar Allan Poe uses comparisons between the ancient past and the present in order to demonstrate his warnings; to achieve that, he refers to ancient philosophers. Among them, he specifically mentions a philosopher named Aries Tottle. Being one of the author's devices of irony, this remark has extensively concerned literary critics (Hayes, 2009; Peeples, 1998). It is commonly believed that Aries Tottle was neither Turkish nor Indian but Greek, perhaps even Aristotle himself (Martínez López, 2011: 179).

Finally, Edgar Allan Poe possibly attempted to satirize two philosophical suggestions which claim that there are only two ways to discover the truth. The first is Aristotle's "a priori" method of deduction and the second is Bacon's "a posteriori" inductive method. Peeples also reached the same conclusion by stating that Poe uses "specifically the deductive method of Aries Tottle (Aristotle) and the inductive method of Hog (Francis Bacon)" (1998: 162). However, Martínez López claimed that "Pundita's early criticism of Aristotle and Bacon, full of deliberate mistakes as it is, probably represents, as commonly seen in satire, the opposite of Poe's own views" (2011: 179). Hence, the American author's attempt to convey his own powerful political message while utilizing references originating from Hellenic literature renders obvious that the Hellenes indeed had a major effect on his storytelling.

\section{A GLIMPSE OF THE END OF THE WORLD FROM A HELLENIC POINT OF VIEW: THE ANATOMY OF "THE COLLOQUY OF MONOS AND UNA"}

Edgar Allan Poe's "The Colloquy of Monos and Una" is a narrative that introduces the readers to the post-apocalyptic story of Monos and Una, two protagonists who are long deceased lovers, reborn in the afterlife. Written in 1839, "The Colloquy of Monos and Una" sets forth a cataclysmic ending of the world. One can quickly unearth that the topic of the protagonists' conversation is death, as they both make an attempt to determine what it means (Carlson, 2007: 6).

According to Jacobs, "one of the persistent themes in Edgar Allan Poe's writings concerns the distortion in the physical universe that attended man's fall from a state of innocence and earthly immortality" (1960: 404). Having been deceased for a long time, Monos discusses a serious change in modern society. According to him, the community has distanced itself from nature and ethics. As Jacobs also mentions, "man's alienation from the universe is a consequence of his guilt" (1960: 409). In fact, according to Monos, death is a 
part of mankind and people should not be afraid of it. He continues to explain that, because of this, mankind is allowed to be reborn in a new, clean and perfect afterlife. Jacobs also exposes Poe's belief that "human nature must be purified by death" while adding that the American author merely suggests that we might have been saved, had we sought beauty instead of knowledge (1960: 404-409).

Afterwards, Monos attempts to describe his feelings while he was crossing the passage from the present world to the afterlife and, as Hoffman points out, the protagonist assesses "the hyper excitation of his senses, his awareness, his eerie awareness that from the wreck and the chaos of all the usual senses, there appears to have arisen a sixth, all perfect" (1972: 175). As Monos lies dying, he hears Una crying and he becomes disoriented, as if he had lost the control over his senses while still retaining them. Tate comments on this part of the tale that "this is not the experience of synaesthesia rendered to our consciousness; to put it as Poe puts it is merely to consider it as a possibility of experience" (1952: 460). This power is completely lost during the last night of Una's life, which she spends next to the tomb of her beloved. The following day Una is lowered into the grave and they are both reborn together.

Upon taking a closer look at the text, one could remark that Poe's need to explore the Universe further requires the incorporation in his tales of characters that are no longer human. Kennedy also points out that the very tension between Poe's gruesome Gothic imagination and transcendental idealism explains the author's perpetuate use of the millennium period in his stories (2001: 14). As Jacobs adds, this particular topic had been dealt with long before anyone else by the Greek poet Hesiod (1960: 404). May also indicates that two crucial notions of this narrative are "Place and Time" (1991: 58). In accordance with the same literary critic's arguments, Poe does not wish to emphasize the literal meaning of place and time but in a metaphorical sense, stressing their use "as ultimate Unity and Oneness" (May, 1991: 58). Thus, one could infer the reasons why Poe's protagonists are named Monos-a word which in ancient and even in modern Greek is translated as "one" or "alone"-and Una-the Latin word also meaning "One". In fact, it has been determined that "The Colloquy of Monos and Una" is Poe's effort to exhibit the need for bright minds to be alone, away from distractions and diversions. As Hoffman concludes, "that is the bliss of Heaven guaranteed us by the intensity of our earthly woes" (1972: 175). Tate was also among the first scholars to attest that Poe deals with "the great framework of the Aristotelian psychology to which the literature of Europe had been committed for more than two thousand years" (1952: 467).

One must not fail to notice the existence of the epigraph at the beginning of the tale, which is written entirely in ancient Greek. As previously mentioned in the section in which "Mellonta Tauta" was analyzed, this specific Hellenic phrase indicates "The things that are in the near future" and its use signals the author's auguring of a bleak future, should his society continue as they are. Hence, the analysis of this particular narrative demonstrates that Poe undoubtedly attempted to convey his political message using elements from Hellenic and 
Latin texts. The dominance of the monad and its portrayal in the tale is propelled by the use of the Hellenic and Latin words "Monos" and "Una", these being undeniable evidence of the existence of Latin and Hellenic influence in his narrative.

\section{THE GREEKNESS OF POE'S APOCALYPTIC VISION: “THE CONVERSATION OF EIROS AND CHARMION"}

Poe's "The Conversation of Eiros and Charmion" is another apocalyptic narrative, first published in "Burton's Gentleman's Magazine" in 1839. Its playfulness has recently caught the attention of a number of scholars-see, for instance, Fernández-Santiago (2011) and Tatsumi (2008). The reader is introduced to two protagonists who are no longer alive, similarly to the previously analyzed tale. Their names appear to have been changed to Eiros and Charmion the moment they died and their conversation focuses on the way the world has ended, as they both try to identify the sequence of events that led to this horrific development.

According to the protagonists, Charmion died ten years before Eiros, the latter having perished during the Apocalypse. Based on Eiros and Charmion's descriptions, a comet has been spotted within the Earth's solar system. People and the astronomers of the time are portrayed as being assured upon predictions of the comet's trajectory. However, what follows is pain and anguish and, as Eiros describes, "a wild change had come over all men; and the first sense of pain was the signal for general lamentation and horror" (Poe, 2014: 390). Apparently, the ancient prophecies about the Earth's future that were once dismissed by the astronomers had finally come to life, and the Earth is destroyed in a hail of fire.

Hoffman was one of the first scholars to plainly state Poe's story was possibly capitalizing on the enthusiasm during the early nineteenth century due to the discovery of several comets and the existence of a variety of predictions about the end of the world. As he distinctly mentions, "by 1839 (this year Poe wrote up this dream of murdering the world), four years after Halley's comet had passed by, America was running a high fever, with apocalyptic visions a common symptom of the nation's mass delirium" (1972: 174). However, following Tate's approach, one can assume that Poe perhaps intended to portray the world's destruction not as a possibility but as "a moral and logical necessity of the condition to which man has perversely brought himself" (1952: 462). Thus, one can deduct that the present tale indeed disguises a political message.

A thorough analysis of the key elements in "The Conversation of Eiros and Charmion" indicates that this story bears numerous characteristics originating from the Hellenic domain. Primarily, I intend to focus on the epigraph at the beginning of the story, since it belongs to Euripides' famous tragedy, Andromache-Poe himself accurately translated the phrase as "I will bring fire to thee". Confirming the above, Hayes (2009), Kennedy (2001) and Peeples 
(1998) have all concluded this narrative is also part of the American author's criticism of the society of his time. Despite the repetitive analyses of the present narrative, none of the aforementioned scholars have attempted to connect Poe's utilization of this epigraph to the political message the American author tries to convey.

In his tragedy, Euripides portrays the story of Neoptolemus, who marries Andromache right after the fall of Troy. She then gives birth to his son, Molossus, and, as the story progresses, Neoptolemus decides to also marry Hermione, with whom he never has a child. During Neoptolemus' absence and succumbing to jealousy, Hermione finds the opportunity to eliminate Andromache. Before she succeeds with her goal, however, the reader encounters Andromache's fierce resistance to her inevitable fate as she perishes in the flames. The following translation of Euripides' extract vividly demonstrates the aforementioned scene:

HERMIONE: Are you going to leave from this holy place which is protected by the goddess?

ANDROMACHE: I will gladly leave but only if I am dead. If I am not dead, though, I will never do that.

HERMIONE: Then your fate has already been decided and I will not wait until my husband's return.

ANDROMACHE: Nor will I ever surrender to you.

HERMIONE: I will bring fire upon you and I will make you leave without any second thoughts.

ANDROMACHE: Light the fire, then. And let the gods see what you are about to do.

(1825: 237; translation and emphasis by author)

As it may be inferred, Euripides describes a scene of annihilation, a tragic moment whose final event uses the element of fire as a means for the tragic act. While focusing on the existence of fire as a key element for the catharsis, one can observe the similarities between Poe's tale and Euripides' tragedy. The latter's use of fire as a means of purification in a similar way to Poe's story indicates such a connection-according to Silverman (1991) and Peeples (1998), Poe's intention was to portray the need for the absolution of society through ultimate unity. Just as in the case of "The Colloquy of Monos and Una", Poe once again illustrates the need for unanimity through fire and eradication. Interestingly, Mossman argues that Euripides also intended to illustrate unity. As he specifically mentions, "unity is created by a central figure in Andromache, but that central figure, around whom the plot is built with infinite care, is one who only appears as a corpse: in fact the central figure of this play is none other than Neoptolemus" (1996: 143). In that sense, Poe's mention of this particular epigraph could be described as a direct link to the ancient Greek tragedy.

Apart from the above, it is important to mention that Poe's choice of names for his characters was probably influenced by ancient Greece. The author's choice of the names Eiros and Charmion may have been intentional. The aforesaid names were first encountered in history within the series of biographies called Parallel Lives, written by Plutarch (c. AD 
46-AD 120). These two particular characters are portrayed by Plutarch as the maidens of Queen Cleopatra, being very loyal and faithful to their mistress. They are depicted as amiable but, most of all, compassionate. Similarly to Poe's Charmion-whose exact phonetic representation of the corresponding Greek word is translated as "source of delight"Plutarch's homonymous protagonist was more experienced and wiser than Eiros. The following extract of Plutarch's work describing the moments after Queen Cleopatra's death could realistically define the above claims:

While people were running and, seeing that the guards had not understood what had happened, they opened the door and they found Cleopatra lying dead on a golden bed, dressed as a queen deserves to be dressed. One woman, the one named Eiros, was slowly dying next to her following her queen's example, whereas the other one, Charmion, was walking dizzy, dying as well, trying to fit her queen's crown perfectly on her head. Then somebody shouted at her: "Have you done it well Charmion?" And she answered: "Very well, actually, as it suits a descendant of kings and queens". She did not say anything else and left her last breath next to her queen's bed. (Plutarch, 2012: 85)

Poe may have desired to employ two playful characters while trying to imagine his vision of the end of the world. Plutarch's Eiros and Charmion incorporate all these virtues and they also come to experience Afterlife, just as Poe's characters do. Undeniably, the exact use of this particular combination of names is a direct reference to Poe's source of inspiration.

In short, the analysis of Edgar Allan Poe's tale as well as its epigraph written in ancient Greek- " $\pi v \rho \sigma$ or $\pi \rho 0 \sigma o 1 \sigma \omega "$ [sic] (Poe, 2014: 386) — have led to the assumption that Poe might have indeed been obsessed by Hellenic literature. Eiros and Charmion, two characters whose names are plainly borrowed from Plutarch's Parallel Lives, along with the Hellenic epigraph fortify the above claim. Meanwhile, the similarities of their roles to those of the homonymous protagonists in Plutarch's tragedy all come to attest a Hellenic influence. Thus, one can see that the Greekness of the present tale is apparent-by the term Greekness I refer to the story's emerging Hellenism that can be identified through the language and the protagonists employed.

\section{THE REASONS WHY POE CHOSE GREECE AS A SOURCE OF INSPIRATION}

While further considering the question that arose in the introductory part of my essay regarding the reasons why Poe chose to include Hellenic notions in his tales, it is important to establish Poe's own thoughts while composing his tales. As previously mentioned, ideas conveyed by Classical literature were mainly forsaken by American Romanticism. In order to 
make safe assumptions as to why Poe utilized Hellenic references I deem it crucial to take into account what has already been stated by academics regarding events that marked Poe's life as well as his writings.

Poe had been introduced to the Hellenic and Latin texts in his pre-teenage years, and it was during this period that he developed a love for Homer and the Classics. Kennedy accounted for a trip that the six-year-old Poe undertook with his family to Europe and, more specifically, to England and Scotland, where he began his primary education (2001: 20). Indeed, as confirmed by the same academic, at this point of his life he found himself as close to Greece as he would ever be. His stay at two boarding schools located in Chelsea and Stoke Newington may well have provided him with the Hellenic knowledge that would later be encountered in his work (Kennedy, 2001: 20-21). In the same vein, Stashower states that "[b]y the age of eleven the boy was studying Horace in Latin and Homer in Greek" (2014: xii); that is also confirmed by Silverman, who also mentions that most of the private academies in Virginia, where he later lived, offered Greek courses (1991: 23). Furthermore, as Kennedy adds, Edgar Allan Poe was not only interested in his Latin and Greek studies but he was excelling at them (2006: xi), whereas Crisman explains that Poe seems to have considered Homer as one of the most important authors that had ever existed (2009: 64). Benton not only confirms this claim but he additionally claims that Poe had continued his Greek inquiries by reading Plato's masterpieces. Quoting once again his own words, "when Poe wrote 'Eleonora', he re-dreamed this dream, this time under the influence of the Platonic model of the Twin Venuses he recalled from the 'Symposium'” (Benton, 1967: 296). Poe's infatuation with Greece is also confirmed by Myers's report in which one can encounter that his love for Greece had led him to lying about having travelled there. More specifically, as Myers sets forth, "Baudelaire falsely claimed that he had traveled on from Mauritius to India just as Poe claimed he had made a journey to Greece" (2000: 267).

In addition to the above, I should mention one of Poe's literary idols: Lord Byron. A statement which is crucially relevant can be located in Silverman's academic exploration of Poe's life: "How deeply the Byron image impressed Edgar is apparent in his six-mile swim on the James river, emulating Byron's celebrated swim of the Helespont, and the stories in Richmond that he had joined the Greeks, as Byron had, in their quest for independence. [...] Byron offered Edgar a perspective from which to evaluate his own life and legitimized his experiences as authentic ones for a young poet to have" (1991: 41).

Clair states that there was a trend during Poe's lifetime supporting Lord Byron and his Hellenic expedition (2008: 177). This movement had led plenty of authors and poets, Poe being among them, to claim that they had fought for the Greek revolution even though they had not. Despite Edgar Allan Poe's claims that he had been to Greece, Clair discloses that “it is known that he got no nearer than Boston, Massachussets" (2008: 177). This statement coincides with the one of Sanidopoulos (2012) who, in his review of Poe's life, states that in 1827 Poe, being moved by the heroic revolution of the Hellenes and following Lord Byron's 
footstep, set sail for Greece with Ebenezer Burling. However, succumbing to the pressure of his parents, Ebenezer soon abandoned Poe. That fact may have been the reason why the latter never reached his final destination. However, Poe's love for Greece and Hellenic literature continued to have a great impact on him until the end of his life and that can also be observed within his tales and verses (Sanidopoulos, 2012).

Furthermore, as Hoffman stressed, the administration of President Fillmore would never accept rebellious messages that would destabilize the democracy of the era (1972: 194). Even though McGann (2014) claims that Poe's political criticism was direct, perhaps the Hellenic language, tragedy and philosophy allowed Poe to disguise his critique while still conveying his political message through his tales.

Hence, having exposed Poe's Classics education (which includes the works of Plato and Homer), his fascination with Lord Byron (who was an active member of the Greek revolution of independence), as well as Poe's later desire to explore Greece-along with his inaccurate claims of having travelled there-, one can see a clear connection between Poe and Greece which may be reflected in his use of Hellenic references in his narratives.

\section{CONCLUSIONS}

The aim of this essay has been to delve into Poe's works focusing on the apparent Hellenic references rather than the Latin ones due to the fact that a systematic examination of the first has never been done. Its main aspiration is to indicate promising evidence of connections between Poe's selected narrations and Greece, and to unearth an additional relationship in Poe's "The Conversation of Eiros and Charmion" that has not been discussed in the research of prominent Poe scholars. Furthermore, given the fact that American Romanticism had probably relinquished the uncritical acquirement of concepts encountered in Classical literature, the reasons why Poe opted for these connections with the ancient Greek realm had to be explored.

As indicated by the analyses of noteworthy scholars, the title of "Mellonta Tauta" itself is a phrase borrowed from the concluding lines of Sophocles' Antigone; through this reference Poe wanted to indicate "these things that are in the future", wishing to warn society of contemporary democracy's imminent dangers. Poe's effort to criticize contemporary society of his time by using Aristotle's "a priori" method of deduction and Bacon's "a posteriori" inductive method was also noted. This particular conclusion was also drawn by Peeples' and Zimmerman's research (1998 and 2005, respectively), and perhaps Poe himself makes it clear through his playful use of the Greek philosopher's name.

Poe's second attempt to castigate his community by once again utilizing the ancient Greek "Mellonta Tauta" was also observed, this case as an epigraph. The Hellenic origin of 
the word Monos-whose meaning was connected to the exact phonetic representation of the Greek word meaning "one" and "alone" - and its importance for the motif of the monad in "The Colloquy of Monos and Una" were also indicated. Jacobs' claim that there are apparent similarities between Poe's tale and Hesiod's works was also presented. The spotlight fell upon one of Poe's post-apocalyptic tales, "The Conversation of Eiros and Charmion", and the fact that its epigraph was borrowed from Euripides' tragedy Andromache. Moreover, the Hellenic origin of the protagonists' names was remarked on, as Eiros and Charmion are two of the protagonists in Plutarch's masterpiece Parallel Lives. Quite surprisingly, this probable connection between Poe's protagonists and Hellenic tragedy has, as yet, not been explored in research dealing with the field of Poe studies. As for the reasons why Edgar Allan Poe has turned to Greece as a source of inspiration, one could believe that his Classical education as well as his limitless respect for the works of Lord Byron, who was an active member of the Greek revolution, might have provided Poe with enough motives to justify the employment of Hellenic references in his storytelling.

To conclude, upon a closer examination of Poe's works, it is rendered obvious that Poe was influenced by Hellenic literary sources-either by Hellenic tragedy, philosophy, or the Hellenic language itself. Poe's employment of all the above-mentioned links to the Hellenic realm may indicate philhellenic tendencies in Poe's narratives, a determination which verifies Sanidopoulos' (2012) claim of Poe's philhellenism. The fact that the author resorted to Greece as a source of inspiration is undeniable since Hellenic allusions are utilized in the American author's stories in his attempt to stress the need for a purer humanity and to criticize the political scene of his time.

Nevertheless, my study only demonstrates the potential of this topic, illustrating the need of additional research. Beyond the shadow of a doubt, Poe's works conceal further Hellenic references that have not been delved into. Future studies should examine Ljungquist's (1980) indications regarding a number of Poe's tales-“The Colloquy of Monos and Una", "Mellonta Tauta", and "The Conversation of Eiros and Charmion" being among them-that explore the daemonic as it is encountered in Hellenic thought. A systematic analysis is essential so that the American author's literary devices, philosophical and political resonances are interpreted while focusing on Filippakopoulou's mention of "Poe's permanence in Greek literature" (2014: 37).

\section{ACKNOWLEDGEMENTS}

The research of this project was supported by CEI Patrimonio (University of Almería). 


\section{REFERENCES}

Ackroyd, P. (2008). Poe. A Life Cut Short. New York, NY: Doubleday.

Baum, P. (1949). Poe's 'To Helen'. Modern Language Notes, 64(5), 289-297.

Benton, R. (1967). Platonic Allegory in Poe's 'Eleonora'. Nineteenth-Century Fiction, 22(3), $293-$ 297.

Brunet, F. (1997). Poe à La Croisée Des Chemins: Réalisme Et Scepticisme. Revue Française D'études Américaines, 71, 44-50.

Cantalupo, B. (2014). Poe and the Visual Arts. University Park, PA: Pennsylvania State University Press.

Carlson, E. (2007). Triangulating Edgar A. Poe. The Edgar Allan Poe Review, 8(2), 6-16.

Claire, W. (2008). That Greece Might Still Be Free: The Philhellenes in the War of Independence. (2nd ed.). Cambridge: Open Book.

Crisman, W. (2009). Poe's Ligeia and Helen of Troy. Poe Studies, 38, 64-75.

Euripides. (1825). Andromache. In C. F. Boissonade (Ed.), Poetarum Graecorum Sylloge. Euripides (Vol. 17) (pp. 221-284). Paris: Lefevre.

Fernández-Santiago, M. (2011). Poe's Play-Full Narratives. The Edgar Allan Poe Review, 12(2), 79 100.

Filippakopoulou, M. (2014). Edgar Allan Poe in Greek Letters. In E. Esplin \& M. Vale de Gato (Eds.), Translated Poe (pp. 37-46). Bethlehem, PA: Lehigh University Press.

González Moreno, B. \& Rigal Aragón, M. (2010). Edgar Allan Poe (1809-2009). Doscientos años después. Cuenca: Universidad de Castilla la Mancha.

Gunn, J. (2010). Science Fiction around the World. World Literature Today, 84(3), 27-29.

Hayes, K. (Ed.). (2009). The Cambridge Companion to Edgar Allan Poe. (6th ed.). Cambridge: Cambridge University Press.

Hoffman, D. (1972). Poe Poe Poe Poe Poe Poe Poe. New York, NY: Doubleday \& Company.

Jacobs, R. (1960). Poe's Earthly Paradise. American Quarterly, 12(3), 404-413.

Kennedy, G. (Ed.). (2001). A Historical Guide to Edgar Allan Poe. Oxford: Oxford University Press.

Kennedy, G. (2006). The Portable Edgar Allan Poe. New York, NY: Penguin Classics.

Levine, S. \& Levine, S. (1986). 'How-to' Satire: Cervantes, Marryat, Poe. Modern Language Studies, 16(3), 15-26.

Ljungquist, K. (1980). Uses of the Daemon in Selected Works of Edgar Allan Poe. Interpretations, 12(1), 31-39.

Marchand, E. (1934). Poe as Social Critic. American Literature, 6(1), 28-43.

Marshall, B. (2011). Review of Agnieszka Soltysik Monnet (2010). The Poetics and Politics of the American Gothic: Gender and Slavery in Nineteenth-Century American Literature. Routledge. The Review of English Studies, 62(256), 666-668.

Martínez López, M. (2011). Ex Nihilo Nihil Fit: Dystopian Satire in Poe's 'Mellonta Tauta'. In E. Llácer Llorca, A. Olivares Pardo \& N. Estévez Fuertes (Eds.), A 21st Century Retrospective View about Edgar Allan Poe / Una mirada retrospectiva sobre Edgar Allan Poe desde el siglo XXI (pp. 169-187). Bern: Peter Lang AG.

May, C. (1991). Edgar Allan Poe: A Study of the Short Fiction. Boston, MA: Twayne.

McGann, J. (2014). The Poet Edgar Allan Poe: Alien Angel. Cambridge, MA: Harvard University Press.

Mossman, J. M. (1996). Waiting for Neoptolemus: The Unity of Euripides' 'Andromache'. Greece \& Rome, 43(2), 143-156.

Myers, J. (2000). Edgar Allan Poe: His Life and Legacy. New York, NY: Cooper Square.

Norman, E. K. (1934). Poe's Knowledge of Latin. American Literature, 6(1), 72-77.

Papazu, M. (1989). The Search for Life and Truth in Edgar Allan Poe's Tales. Atlantis, 11(2), 125136.

Peeples, S. (1998). Edgar Allan Poe Revisited. New York, NY: Twayne.

Peeples, S. (2004). The Afterlife of Edgar Allan Poe. New York, NY: Cardem House.

Peris, M. (1980). Greek Motifs in the Jatakas. Journal of the Royal Asiatic Society Sri Lanka Branch, $25,136-183$. 
Plutarch. (2012). Antonios. In K. Stefanopoulos (Ed.), Anthology of the Ancient Greek World (pp. 53127). Athens: Educational Institute of Athens.

Poe, E. (2014). The Complete Tales and Poems of Edgar Allan Poe. New York, NY: Race Point.

Richard, C. (2009). The Golden Age of Classics in America. Cambridge, MA: Harvard University Press.

Rigal Aragón, M. (Ed.). (2011). Los legados de Poe. Madrid: Síntesis.

Sanidopoulos, J. (January 19, 2012). Edgar Allan Poe As A Philhellene [Blog Post]. Retrieved July 1, 2015 from http://www.johnsanidopoulos.com/2012/01/edgar-allen-poe-as-philhellene.html.

Schina, K. (2013). 21 istories kai "To Koraki” [21 stories and "The Raven"]. Athens: Metaixmio.

Silberschlag, E. (1977). Greek Motifs and Myths in Modern Hebrew Literature. Proceedings of the American Academy for Jewish Research, 44, 151-183.

Silverman, K. (1991). Edgar A. Poe. A Biography. Mournful and Never-Ending Remembrance. New York, NY: Harper Perennial.

Stashower, D. (2014). Introduction. In E. Poe (Ed.), The Complete Tales and Poems of Edgar Allan Poe (pp. xi-xxiii). New York, NY: Race Point.

Tate, A. (1952). The Angelic Imagination: Poe and the Power of Words. The Kenyon Review, 14(3), $455-475$.

Tatsumi, T. (2008). Classic Cosmogony. Science Fiction Studies, 35(1), 145-149.

Vincelette, E. (2008). Beauty, Truth, and the Word: The Prophecy and Theology of Poe's Eureka. The Edgar Allan Poe Review, 9(2), 36-54.

Vines, L. (Ed.). (1999). Poe Abroad: Influence, Reputation, Affinities. Iowa City, IA: University of Iowa Press.

Zimmerman, B. (2005). Edgar Allan Poe: Rhetoric and Style. Montreal: McGill-Queen's University Press. 